\title{
Legal Certainty of Oil Palm Plantation Land Title Holder
}

\author{
Rio Christiawan \\ \{rchristiawan@gmail.com
}

Universitas 17 Agustus 1945 Jakarta, Jakarta, Indonesia

\begin{abstract}
The certificate of land title issued by the government is an acknowledgment of ownership of a legal land object. In this case, prior to issuing land title certificates, the government has first conducted a review of both physical plots of land and related legality, including in this case the legality of the area to ensure that the certificates issued do not enter the forest area. The problem now is that many land objects that already have land title are questioned by the forestry institution because they are included in the forest area in accordance with the latest overlay of forest area maps. This study looks at the legal certainty aspects of land certificates against changes in forest area maps. This research is a juridical normative supported by legal material and uses a deductive method in finding conclusions on the issues.
\end{abstract}

Keywords: Land Title, Legal Certainty, Map Amendment

\section{Introduction}

Referring to the legislation that certificate of land rights is proof of ownership of land rights. This means that as long as the certificate is used in accordance with its designation and is not revoked by the government, the government must provide protection to the certificate holder. Protection of certificate holders by the government is a form of legal certainty provided by the government to the holders of land rights. In this case the meaning of the certificate is the right to use according to the designation, the meaning of the right itself is the interest protected by law [1].

This means that in this case the interests of the use of the certificate must be protected by the government. In this case the certificate is the legal basis for the holder to carry out the allotment of the certificate. Before iss uing a certificate, the governmentcertainly refers to the regional spatial plan, so that the allotment of the certificate is not in conflict with other spatial planning plans.

The Right to Cultivate (HGU- Hak Guna Usaha) certificate is one of the important permits in oil palm plantations considering that HGU is proof of ownership rights to a land. HGU is granted if the applicant is a legal entity, in case of the individual applicant then the certificate shall be the right of ownership (SHM-Sertifikat Hak Milik). In case an individual with SHM status transfers his rights to a legal entity, the rights shall decrease from SHM to SHGU (no period of validity in SHM). In addition to proof of ownership rights, certificates are also commercial requirements that are required to obtain funding from banks and other financial institutions, because the certificate will be the mortgage as collateral.

HGU may be issued at the district, provincial or central level depending on the level of rights applied. The agency that is sues both the decree and the HGU certificate is the National Land Agency (BPN- Badan Pertanahan Nasional). The stages of HGU submission are divided into three parts, namely the cadastral stage, the stage of Committee $B$ and the stage of is suance of a decision on the granting of rights and finally after the applicant pays land and building transfer duty (BPHTB), then the HGU certificate will be is sued by the local BPN office (where the land is located).

To apply for a HGU with an allotment of oil palm, all technical licenses described in the previous chapter must already be owned and are still valid. The application letter is submitted through the local land agency office (BPN). After that BPN will follow up with cadastral activities carried out by the local BPN (district / city) and/or Provincial BPN. The cadastral stage begins by examining the applicant's documents in preliminary exposures carried out by the local BPN, after the applicant's documents have been declared complete, the BPN team will conduct a field physical inspection.

Field physical inspection will include measurements of land plots which certificate be applied of. The results of field physical inspection and measurements of the land plots are used as guidelines for the installation of cadastral stakes. These cadastral stakes will be used as a basis for constructing maps of land plots, with a map of land plots being made, the land 
plots which certificate be applied of will already have an identification number of land plots (NIB- Nomor Induk Bidang) which is printed on the map of land plots.

The next stage after the cadastral process and the is suance of a map of land plots is the stage called 'committee B'. At this stageBPNinvites relevant agencies, regents / mayors and related offices including community representatives to conduct physical inspections of land plots to ensure that the land to be granted land rights (HGU) is not problematic and not in legal defects or disputes.

This stage of committee B invites the regent/ mayor as the head of the region along with the relevant agencies and community leaders to ensure that the land parcels listed in the land parcelmap do not have a problem to be certified. This includes examining land tenure and growing compensation (GRTT-Ganti Rugi Tanam Tumbuh) documents.

The results of the field inspection and the hearing of the committee B team together with the regent/ mayor and related agencies, as well as community leaders were outlined in the minutes of committee B. Furthermore, the map of the land plots and minutes of committee B will be used as the basis for the is suance of a decree (SK) for granting HGU. The HGU decree can be granted by the regency / city, provincial or central level BPN, the authority of the is suance depends on the area of land to be applied for the HGU. The HGU decree contains conditions for granting HGU for oil palm plantations such as the period (generally 25-35 years), the development of plas ma plantations / community partnerships and other conditions.

After the HGU decree is is sued, the applicant must pay land and building transfer duty (BPHTB). After the applicant pays the BPHTB tax, the local BPN may issue a HGU certificate with an attached HGU map, as proof that the land rights have been registered.

After going through such a detailed process, the holder of the HGU certificate must be protected and provided legal certainty. The fact is that the current holder of the HGU certificate does notobtain legal certainty, specifically due to changes in the map of the forest area. The problemis the map of forest areas always changes from time to time. Ironically, the is suance of a certificate of land rights also involves the forestry office, but now the forestry office actually questions many HGUs located in forest areas according to the latest spatial map is sued after the HGU certificate.

The Government is sued the Republic of Indonesia Presidential Regulation No. 9 of 2016 concerning the Acceleration of the Implementation of the One Map Policy at the Level of Accuracy 1: 50,000 Scale intended to support government programs through economic packages, especially in the simplification of licensing and to realize effective natural resource governance. Understanding the Presidential Regulation regarding one map policy was issued to resolve the problem of geospatial information that is out of sync between government agencies and other stakeholders.

Through the one map policy, it is expected that there will be guidelines for the management of natural resources and their law enforcement, because in reality until this time, license application especially businesses in the field of Natural Reso urces must undergo through a variety of licenses, almostall of which shall attach map to those licenses (starting from Provincial / Regency spatial maps, location permits, Plantation Business Permits, Environmental Permits, Production Forest Area Release Permits, Land Clearing Permits, to conclude, all certificates shall have their respective maps) of which are often out of sync that enforcing the law over the situation faces difficulty because each maps as a reference are different and the map is issued by different agencies [2].

In the perspective of increasing investment as an objective of the economic package launched by President Joko Widodo that simplifying the licensing process is something that must and is being conducted by the government. The source of the problem of business 
licensing, especially in the field of natural resources, is related to maps which are always integrated into permits. No synchronization of respective map owned by each agency and stakeholders causes the guarantee of investment certainty becomes weak, on the other hand the sectoral ego of each stakeholder to maintain their respective guideline maps results in at the time a problemoccurs above the area of the business permit, potential arise of debate and interpretation providing uncertainty in investing.

The problem discussed in this study is whether the certificate of HGU of oil palm plantations is proof of ownership of land rights protected by the government in the event of changes in the area map?

\section{Purpose}

To evaluate the issuance of amendment of the forest area map, that the results of this study hopefully may provideguidance for the government in this case through the relevant agencies in making amendment to the forest area map so that it does not overlap with certificates of land rights, especially right to cultivate certificates (HGU).

The results of this study are also expected to provide guidance to the government related to overlapping of certificates of HGU that have been is sued with maps of forest areas changes, so that the settlement is expected to be able to realize legal certainty and not interfere with the investment climate of oil palm plantations and processing which is the largest source of foreign exchange for Indonesia.

\section{Method}

The method used in this paper is a normative juridical research method with focus on conducting juridical studies on the protection and legal certainty of holders of right to cultivate certificates (HGU) against amendment in maps of forest areas. To achieve the above purpose, literature study is used, using legal material to ans wer the problem formulation. In this case, court decisions, laws and regulations, doctrines and supporting literature that be divided into primary, secondary and tertiary legal materials.

This paper uses a normativelegal research approach by doing an abstraction of the process of deduction from the prevailing positive legal norms, namely examining the law as a positive norm using deductive thinking and based on coherent truth, where the truth in this study has been declared credible without having to go through a testing or verification.

The data intended in this study are materials or facts or may also be interpreted as a source of information. While the legal material intended in this study consists of primary legal material and secondary legal material. Primary legal material is an authoritative legal material which means that it has regulatory authority, minutes or official records, and court decisions. Whereas what is meant by secondary legal materials are books (expert opinion), journals, and everything that can provide guidance for researcher.

The data obtained are analyzed so that rational reasons can be found regarding the formulation of the problemand its analysis. The results of the processing are analyzed and then discussion conducted and conclusions drawn from the use of the determination to delay the execution of decisions that have permanent legal force. 


\section{Result and Discussion}

\subsection{Result}

Lawrence M. Friedman [3] outlines that to realize legal certainty must regard the legal substance, legal structure, legal culture and legal impact. This one map policy can be considered as an effort to rectify the legal substance, especially in the is sue of overlapping between issuance of HGU certificates and changes in the forest areas map in the implementation of business activities in the field of natural resources such as the oil palm plantation and processing industry.

One map policy, in addition to simplifying procedures for granting permits, is hopefully that at the time it is realized, will result in integrated spatial guidelines used for reference to the issuance of certificates or changes to regional maps so that in this case it can provide investment certainty and can become rules for across departments in enforcing law and is suing permits.

Good law enforcement requires an adequate legal substance because without an adequate legal substance the law is always in a multi-interpreted area, that multi-interpreted area will be eliminated by one map policy specifically related to zoning in the business area. With the legal substance of the license that is supported by one map policy that is appropriate and accurate, this not only provides legal certainty to investors but also provides a basis for the process of law enforcement.

Legal certainty must be based on valid guidelines and basis, because at this time there is still law enforcement based on indicative maps and based on different maps and not well consolidated. This one map policy is a momentumto improve the legal substance, especially in the certificate issuance guidelines which also become a guideline for all agencies and stakeholders so that a geospatial reference can be compiled which is the only standard and database at the level of detail (1: 50,000) so that the one map policy of definitive nature can be a reference for law enforcement in the field of natural resources be achieved.

With a good legal substance has been arranged, automatically related institutions have the same guidelines so that multiple interpretations between agencies can be removed with a one map policy be provided a legal umbrella. The legal structure also sees from the pers pective of law enforcement officers with a one map policy, that the actions of pers ons who mis use their positions and make use of the multi-interpretation situation can be minimized because they can be monitored by many parties.

The impact expected in the future with this one map policy is to be able to encourage the use of geospatial information for the implementation of national development and to support the realization of the government's priority agenda, so let us hope and support this one map policy can be immediately resolved by fair preparation for all stakeholders .

\subsection{Discussion}

Humans in living with other people need rules that are mutually agreed upon, so that disputes do not occur between people. Both legal rules and non-legal rules are required. Legal and non-legal rules recognize two kinds of concepts, namely the concept of rules/norms and the concept of principle.

The law in its construction is motivated by the principle of law which is the basic thought in the formation of laws and regulations, the principle of law is the basic thought behind the construction of concrete legal regulations as stated in the legis lation thoughts. The purpose of 
the law is as a tool for social change so that if the law can be implemented properly the purpose of the law can bring happiness to as many people as possible.

Utilitarian thinking provides an understanding that law must provide benefits and happiness for as many people as possible, law can provide benefits and happiness for as many people as possible if each pers on feels that there is justicein the law, so that with justice in the law implementation, legal certainty will be realized.

Justice is the main pillar of the law, as explained above that after justice is realized and can be experienced by all citizens, the benefits of law will be experienced, in this case that the understanding of benefits is that all Indonesian citizens may experience development in the health sector in accordance with the goal of independence.

Jhering, who expres sed that the law is a fusion of community interests, further clarifies the philos ophical basis of law to realize legal certainty in society, as well as its manifestations in laws and regulations. The Jhering focus of definition of interest is something that determines in law, specifically the community interests. It is the community's interest that becomes the core of the law [4].

Furthermore, the law should be able to be a tool that can be used to overhaul an unjust power structure, so that mutual prosperity can berealized. Law in Indonesia should be able to realize the ideals of social justice as formulated in the fifth precepts in the Pancasila.

In a limited cabinet meeting on August 24, 2016 with the agenda to discuss agrarian reform it was revealed that in rural areas, the problem of poverty, inequality and the difficulty to get employment were the main problems that wou ld be overcome by agrarian reform so that the direction of agrarian reformin this working cabinet was the realization of justice in land tenure, ownership, use and utilization of land, territories and natural resources.

In line with this, the oil palm plantation and processing industry is the backbone of the community's economy and the main contributor to foreign exchange. In an effort to accelerate agrarian reform the President is sued Presidential Regulation No. 45 of 2016 concerning the 2017 Government Work Plan which places agrarian reform as a national priority. The regulation was made in order to provide a stronger legal basis for labor-intensive sectors such as the oil palm plantation and processing industry.

Now the oil palm industry has become the foundation of many people's economies. The oil palm industry has been deregulated with current regulations guided by sustainable development to realize development based on green growth economy s o that with the creation of regulations based on the concept of green growth economy, a balance between economic interests and conservation interests will be created, so as to create a balance between the interests of people, profits and the planet [5].

Related to overlapping ownership of the HGU certificate of the plantation area with the completion of the status of the forest area must be done in a participatory manner by first collecting dataand determining the forest area as outlined in an integrated map so that there is legal certainty for all parties considering the output of this series of activities is the granting of land management rights and certification of land ownership, including re-measuring areas that are still in conflict for settlement based on a conflict map prepared in a participatory manner involving all affected stakeholders [6].

In parallel, the licensing and supervision sector improvements must be carried out by conducting a review of the Right to Cultivate and license that is not used properly because the target of identification of abandoned land that is the foundation of land redistribution in the agrarian reform program has not yet been optimal. In this case includes review of the implementation of cooperation contracts between corporations and the community that must 
be ensured to meet a sense of justice because ultimately the purpose of the is suance of this certificate is economic equality.

Decree of the Coordinating Minister for the Economy No. 73 of 2017 concerning the Agrarian Reform Team can be positively regarded as the seriousness of the cabinet in completing agrarian reform. After the president appointed the coordinating minister for the economy as the leading sector, it appeared that the agrarian reform team works in a bureaucratic way, considering that in the teamseveral working groups formed with respective sectoral egos, plus the incompleted one map policy program has not created an integrated guideline. The unsynchronized performance between the working groups may be due to the absence of concrete legal regulations that are able to harmonize the provisions between the agrarian and forestry sectors.

In December 2018 the government issued a one map portal, but the one map portal launched by the government in its implementation is still far different fromthe one map policy concept as stipulated in Presidential Regulation number 9 of 2016. The one map portal has not yet been used as a cross-agency map reference.

But in reality until now each agency still has its respective map and spatial planning. For example, until this time one of the requirements for HGU process is to obtain clarification from the forestry agency and the spatial planning agency, even though the status of the related area has been clearly recorded in Plantation Busines s Permit and Location Permit. Until this time, every agency still publis hes an indicative map with a scale of 1:250,000, Research and Development Agency of the Ministry of Agriculture and Plantations (Balitbang Kementerian Pertanian dan Perkebunan) [7], explains the meaning of the indicative map is that the map is considered true until proven otherwise, it can be imagined how complex the land use and spatial issues in Indonesia.

Ideally, a one map portal should be able to function as data sharing between agencies so that there is a unity of land use and spatial planning guidelines. With the unity of land use and spatial planning guidelines, OSS will be able to function fully and optimally to simplify and facilitate licensing and eliminate corrupt practices that often occur because of the complexity of the bureaucracy.

Currently referring to the green growth economy model that has been conceived since the StockholmDeclaration 1972. The concept of green growth economy itself is regarded as a middle ground of conflict between conservation and developmentalist pers pectives oriented towards the development of oil palm lands. Point 13 of the StockholmDeclaration states that "In order to achieve a more rational management of resources and thus to improve the environment, states should adopt an integrated and co-ordinated approach to their development planning so as to ensure that development is compatible with the need to protect and improve the human environment for the benefits of their population".

Contradictory regulations eventually lead to a focu s on achieving green growth economy through theoil palm industry and its CPO derivatives are constrained. In the end this has a commercial impact, considering that Indonesian CPO buyers generally come fromabroad, and considering that ISPO has notbeen able to optimally guarantee environmental su stainability, buyers generally require international environmental feasibility certification, namely RSPO (Round Sustainable Palm Oil) for premium prices.

In the conflict between law and jus tice, they are closely interrelated, the community needs to be regulated fairly, then the law as one means to regulate people's lives must reflect the values of justice. Law without justice can be a tool of oppression. The law is a means of social control to prevent and act against allinjustices that occur in society. Justice is a constitutive element of law, so unjust laws are fragile because they do not have ethical legitimacy. 
In this case as the results of the Earth Summit in Rio de Janerio, Brazil in 1992, which emphasized the concept of sustainability development which continued at the Yohannesburg meeting in 2002, gave rise to a new principle in the business world, namely triple bottom line concept.

This means that in this case related to changes in the map of the area in the area that already has a certificate of HGU, it must follow the procedure that is the local National Land Agency (BPN) identify and research the land that has been granted a Right to Cultivate (HGU), either in the form of a decree permit or HGU certificate to plantation companies.

In case the results of the identification and res earch indicate that there is an indication of abandoning the land, then the relev ant company is given the First Warning Letter. A period of time is granted in such warning letter so that the company as the rights holder may cultivate, use, and utilize the land in accordance with the condition or nature and purpose granting of their rights, and submitting periodic reports on the process of exploitation, useand utilization. When theallotted time period expires, the local BPN will monitor and evaluate the progres $\mathrm{s}$ made.

In case the contents of First Warning Letter are not implemented by the company, BPN may is sue Second Warning Letter. Furthermore, in case the contents of Second Warning Letter are als o not implemented, the company will be granted the Third Warning Letter (last). Meanwhile, in case the contents of the last warning letter are not implemented, BPN shall impose sanctions in the form of land status determined as abandoned land, abolition of rights, termination of legal relations, and affirmation of the status of land to land which is directly controlled by the State [8].

The next process is that the local BPN submits a letter to the Central BPN stating that based on the results of the latest measurement / review that has been carried out, the indicated abandoned land can be removed from the BPN database of indicated abandoned land. The contents of the letter may mention, inter alia, the actual condition of the land still controlled by the community and land acquisition has not yet been carried out, the existence of plas ma development in the HGU area which was originally a HGU for the Core estate, but over time and the development of the surrounding environment, there are demands from the community to establish plasma, even though at the time HGU was is sued there was no obligation for the company to build plasma.

According to Lips ey and Stainer, is suing a regulation mus tregard the correlation between cost and efficiency, while the intended efficiency in the regulation is: Efficiency will be used to mean exploiting economic resources in such a way that goods and services are maximized [9]. As Comparis on, the theory of efficiency in law mentions that:

"Efficiencyas the allocation of social resources to their highest valued uses at minimum cost. Cost can be defined to consider not onlymarket costs butalsonon-market costs such as injury to individuals or the environment" [10]. Economic Analysis of Law in this case is that in the is suance of a regulation mustconsider who is entitled to these res ources, including the form of legal protection that has been provided.

According to Guido Calabresi that in the is suance of a legal regulation must consider 3 main things namely: First, the law must consider the primary cost and the parties losses, second, the law should consider secondary cost, those involve in shifting the lost, or risk of loss between the parties this include the costs associated with bargaining; Lastly the law shouldalso accountfor tertiery cost, the cost of administering the disputes resolution system [11]. 


\section{Conclusion}

That regulations in the field of environmental law are juridical instruments for environmental management and utilization, not just environmental protection, so the definition of environmental regulations is "Het juridisch instrumentarium, dat ten dienste staat van dit milieubeheer is het milieurecht. Milieurecht is dus het recht, dat in ruimste zin betreking heeft op het natuurlijk milieu. De Omvang ervan hangt samen met en wordt bepaald door de omvang van het milieubeheer." (Thelegal instruments at the service of environmental management are environmental law. Environmental law is therefore the law that in the broadest sense relates to thenatural environment. Its scope is related to and determined by the extent of environmental management.")

Efficiency in relation to legal theory in the framework of economic analysis of the law is also associated with a value (value applied) with the value of community satisfaction, in comparison Elliks on believes that people often ignore or otherwise fail to respond to the implementation of applicable law and when they try to follow the law in effect, there are differences in interpretation regarding the applicable legal signs.

The environmental law regulation has the nature of planning and a means to study across legal instruments and between interests to provide direction to the rulers' decisions that can be accepted intersubjectively, whereas the synchronization function of the policy put forward by the legal regulations is the government's means of aligning policies between government agencies and public legal entities which are interrelated.

In accordance with the perspective of justice, the wider community, according to existentialism thinking, that humans exist in this world along with others, with the understanding of justice that gives others what they are entitled to, thus the Constitution has provided every citizen the right to enjoy the regulation of important production sectors are controlled by the state and are used as much as they are for the prosperity of the people.

Constructing regulations on the utilization of the region in Indonesia must be guided by thoughts on critical legal studies that emphasize that, regulations drafted to create false legitimacy means mystification occurs by using complicated legal procedures and difficult language to understand as a tool to suppress and rule of law shackled by contradictions that override basic principles in law so that they are not neutral.

In the contradiction between legal certainty on the holders of right to cultiv ate certificates for oil palm plantations and the arrangement of the functions of forest areas should refer to conditions of justice that are often associated with the law, because the law is one means of effective social control to prevent or take action on all forms of injustice that occur in the community. Law is not synonymous with justice, because sometimes there are legal products that contain elements of injustice. The law is one of the means that can be used to realize justice as envisioned by many people.

\section{References}

[1] Jazuli, Proof of Forestry Crime. Jurnal Hukum Verstek 5 (2), 2016, 45.

[2] Rasio Ridha Sani, Violation of Law in Forest Area Management. Focus Group Discussion, KLHK, $4^{\text {th }}$ November 2017, 5.

[3] Friedman, Legal Theory (original title), translation tittle: Legal Theory \& Philosophy: Philosophical Idealism and the Problem of Justice. Jakarta: Rajawali Press Publishing $1^{\text {st }}$ edition, 1991, 65.

[4] Bernard L. Tanya, Justice in the Law. Jakarta: Genta Publishing, 2001, 180.

[5] Solahudin Jacob, Plantation and Sustainability. Kuala Lumpur: RSPO Publising, 2018, 43.

[6] Nur Azni, Forest Area Legality. Malang: Bayu Media Publishing, 2015, 98. 
[7] Balitbang Kementerian Pertanian dan Perkebunan, Guidelines for Using Indicative Maps. Kementerian Pertanian dan Perkebunan, 2000, 56.

[8] Tim Teknis Badan Pertanahan Nasional, Guidelines for Socialization of Abandoned Land. BPN, $2013,45$.

[9] R. Elikson, Bringing Culture and Human Frailty to Rational Actors: A Critique of Classical Law and Economics. Journal of Chicago-Kent Law Review Vol. 65, 1989, 23.

[10]Ronald Coase, The Problem of Social Cost. The Journal Law and Economic Vol. 3, 1960, 1.

[11]Guido Calabresi, The Cost of Accidents. Yale Law Review Vol. 79, 1970,130. 